\title{
FORMATION OF BEETROOT SEEDLINGS IN DIFFERENT PROTECTED ENVIRONMENTS, SUBSTRATES AND CONTAINERS IN AQUIDAUANA REGION, STATE OF MATO GROSSO DO SUL, BRAZIL
}

\author{
LETÍCIA C. DE OLIVEIRA ${ }^{1}$, EDILSON COSTA ${ }^{2}$, \\ JULISSANDRA A. DA S. CORTELASSI ${ }^{3}$, EDSON T. RODRIGUES ${ }^{4}$
}

\begin{abstract}
This study with beetroot seedlings, cultivar Top Tall Early Wonder, was carried out at the State University of Mato Grosso do Sul (UEMS/Aquidauana), from October to November 2008. Three environments of cultivation were used: greenhouse; nursery with monofilament screen of $50 \%$ of shading; and nursery with aluminized thermal reflective screen of $50 \%$ of shading. In these environments, three polystyrene trays of 72, 128 and 200 cells, filled with four substrates, were tested: soil; Plantmax ${ }^{\circledR}$; coconut fiber and vermiculite. There were no replication environments and then each one was considered an experiment alone. For each environment, it was adopted a completely randomized design in factorial scheme $3 \times 4$ (three trays $\mathrm{x}$ four substrates), with four replications, performing individual analysis of variance and joint analysis of experiments for environment comparisons. The monofilament screen is the best environment for seedlings produced in tray of 72 cells, and the greenhouse was the best environment for seedlings produced in trays of 128 cells. The best seedlings were formed in the tray of 72 cells. Vermiculite was the best substrate.
\end{abstract}

KEYWORDS: Beta vulgaris, protected cultivation, propagation.

\section{FORMAÇÃO DE MUDAS DE BETERRABA EM DIFERENTES AMBIENTES PROTEGIDOS, SUBSTRATOS E RECIPIENTES NA REGIÃO DE AQUIDAUANA-MS}

RESUMO: Pesquisa com formação de mudas de beterraba, cultivar Top Tall Early Wonder, foi desenvolvida na UEMS/Aquidauana, nos meses de outubro e novembro de 2008. Foram utilizados três ambientes de cultivo: estufa agrícola; viveiro de tela de monofilamento, com $50 \%$ de sombreamento, e viveiro de tela termorrefletora aluminizada, com 50\% de sombreamento. No interior destes ambientes, foram testadas bandejas de poliestireno de $72 ; 128$ e 200 células, preenchidas com quatro substratos: solo, Plantmax ${ }^{\circledR}$, fibra de coco fina e vermiculita. Por não haver repetições dos ambientes, cada um foi considerado um experimento. Para cada ambiente de cultivo, foi adotado o delineamento experimental inteiramente casualizado, em esquema fatorial $3 \times 4$ (três bandejas x quatro substratos), com quatro repetições, realizando análises de variâncias individuais e análise conjunta dos experimentos para a comparação dos ambientes de cultivo. A tela de monofilamento foi o melhor ambiente para as mudas produzidas na bandeja de 72 células e, para as produzidas na bandeja de 128 células, foi a estufa agrícola. As melhores mudas foram formadas na bandeja de 72 células. A vermiculita mostrou-se o melhor substrato.

PALAVRAS-CHAVE: Beta vulgaris, cultivo protegido, propagação.

\section{INTRODUCTION}

For the horticultural crops to be competitive and profitable, it requires that all stages of production, from the preparation area, through the purchase of seed and seedling production, reaching the post-harvest handling and marketing, to be accurate and discerning, and to seek to

\footnotetext{
${ }^{1}$ Universidade Estadual de Mato Grosso do Sul (UEMS), Aquidauana, letícia_agroaqui@hotmail.com. Bolsista PIBIC

${ }^{2}$ Prof. Adjunto, UEMS, Cassilândia, mestrine@uems.br.

${ }^{3}$ Eng $^{\mathrm{a}}$ Agrônoma, UEMS, Aquidauana, jucortelassif@ @otmail.com.

${ }^{4}$ Prof. Adjunto, UEMS, Aquidauana, etalarico@gmail.com.

Recebido pelo Conselho Editorial em: 31-10-2011

Aprovado pelo Conselho Editorial em: 11-1-2012
} 
maximize their productive potential. The formation of high quality seedlings provide better adaptation and yield of the field, as observed for lettuce and beetroots (LEAL et al., 2011).

As an important vegetable (GRANGEIRO et al., 2007), the beetroot (Beta vulgaris L.), belonging to the family Chenopodiaceae, is considered a "strong" food in a child's diet, because it is rich in iron (TAKUSHI et al., 2006). In Brazil, its cultivation is exclusively of the table varieties, but in other countries of Asia, North America and Europe there are the sugar and forage varieties. The beetroot culture has been established by direct sowing, however, the crop fields are not uniform due to the poor germination, decreasing productivity. Thus, it is feasible the establishment of beetroot seedlings in trays due to their adaptation to transplantation, unlike other tuberous vegetables (GUIMARÃES et al., 2002).

In the Pantanal region, polystyrene trays with 72 cells provide beetroot seedlings of high quality when grown in substrate containing "soil +7 or $14 \%$ of organic compost", (LEAL et al., 2011), as observed for lettuce seedlings. Trays of 128 cells and 200 cells are most feasible for the formation of lettuce seedlings (MARQUES et al., 2003) in the state of São Paulo, however, among nurserymen, trays of 200 and 288 cells stand out, who look for taking advantage of the spaces of the protected environment and the economy of substrates (TRANI et al., 2004).

The vegetable ambience is the set of elements that composes the climatic conditions of the production area and aims to identify the best micro-climatic conditions for plant growth and better yields and productivities. Studies with vegetable ambience in seedling production of vegetables have been developed by COSTA et al. (2009) and COSTA et al. (2010) with cucumber, and COSTA et al. (2011) with the eggplant.

With small production and few researches in vegetables, along with increased consumption, the State of Mato Grosso do Sul cannot supply its internal market. Thus, it fills the need for horticultural products through acquisition in other Brazilian states, of approximately $85 \%$. The largest suppliers are Paraná and São Paulo, producing and borders states (BOLETIM ANUAL, 2011).

Given the above, this study aimed to evaluate the formation of beetroot seedlings in trays and substrates within different protected cultivation environments, in the Upper South Pantanal of Mato Grosso do Sul.

\section{MATERIAL AND METHODS}

The experiments of seedling beetroot (Beta vulgaris L.), cultivar Top Tall Early Wonder, in different commercial substrates, soil and organic compost, using polystyrene trays in different protected environments, were conducted in October and November 2008, at the State University of Mato Grosso do Sul, Aquidauana Unit, which is located $147 \mathrm{~m}$ altitude, $-20^{\circ} 28^{\prime} 16^{\prime \prime}$ latitude and $-55^{\circ} 47^{\prime} 14^{\prime \prime}$ longitude. The climate according to Köeppen Aw is defined as humid tropical climate, and average annual temperature of $29^{\circ} \mathrm{C}$.

It was used three environmental conditions: (A1) a greenhouse in an arc $(8.00 \mathrm{~m} \mathrm{x} 18.00 \mathrm{~m} \mathrm{x}$ $4.00 \mathrm{~m}$ ) of galvanized steel structure, with zenith opening, covered with polyethylene film of $150 \mu \mathrm{m}$, light diffuser, with thermal reflective screen (Aluminet ${ }^{\circledR}$ ) of 50\% under the screen, and front and side locks with monofilament screen of 50\% shade; (A2) agricultural nursery of galvanized steel structure $(8.00 \times 18.00 \mathrm{~m} \times 3.50 \mathrm{~m})$, closing at $45^{\circ}$, with monofilament screen of $50 \%$ shade (Sombrite $\left.{ }^{\circledR}\right)$; and (A3) agricultural nursery of galvanized steel structure $(8.00 \mathrm{~m} \mathrm{x}$ $18.00 \mathrm{~m} \times 3.50 \mathrm{~m}$ ), closing at $45^{\circ}$, with thermal reflective screen of $50 \%$ shade (Aluminet ${ }^{\circledR}$ ).

Because there are no repetitions of environmental conditions, each one was considered an experiment, and inside them the following treatments were tested: three containers, being the polystyrene trays of 72; 128 and 200 cells designated of R1, R2 and R3, filled with four substrates (S1) soil (Table 1), (S2) Plantmax ${ }^{\circledR},(\mathrm{S} 3)$ thin coconut fiber, and (S4) vermiculite. 
The containers R1, R2 and R3 had the following dimensions, respectively: $5.0 \mathrm{~cm}$ wide by $12.0 \mathrm{~cm}$ high and volume of $121.2 \mathrm{~cm}^{3}$ per cell; $3.5 \mathrm{~cm}$ wide by $6.2 \mathrm{~cm}$ high and volume of $34.6 \mathrm{~cm}^{3}$ per cell; and $2.8 \mathrm{~cm}$ wide by $6.0 \mathrm{~cm}$ high and volume of $22.3 \mathrm{~cm}^{3}$ per cell.

For evaluation of the containers and substrates for each culture environment, it was used the completely randomized design in factorial $3 \times 4$ (three trays $\mathrm{x}$ four substrates) with four replicates, each replicate was the mean of four seedlings. Initially, the data were subjected to analysis of variance of individual containers and substrates, in each growth environment, for further evaluation of the mean squares of the residues (BANZATTO \& KRONKA, 2006), and analysis of the environments. Means were compared by Tukey test at $5 \%$ probability, using the software SISVAR 5.3 (FERREIRA, 2010).

All substrates were fertilized with organic compost Organosuper ${ }^{\circledR}$, at $15 \%$ of the volume, and doses of $2.5 \mathrm{~kg}$ of simple superphosphate $\left(\mathrm{P}_{2} \mathrm{O}_{5}\right), 0.3 \mathrm{~kg}$ of potassium chloride $(\mathrm{KCl})$ and $1.5 \mathrm{~kg}$ of lime filler (PRNT of $100 \%$ purity) per cubic meter. No nitrogen was applied, because it was considered that a fraction of the levels was present in the organic compound, in mineral form (ammonia and nitrate).

It was used the commercial coconut fiber Golden Mix 47® (Coconut fiber of thin texture, HT vegetables). The soil was obtained from the campus of Aquidauana, State University of Mato Grosso do Sul, in the layer of 10-40 cm (Table 1). The characteristics of the organic compound are: $\mathrm{pH}=6.51$, Organic carbon $=26.2 \%$, Humidity $=4.56 \%$, Nitrogen $=1.83 \%$, Phosphorus $=0.96 \%$, Potassium $=0.35 \%$, Calcium $=6.24 \%$, Magnesium $0.88 \%$, Sodium $=0.23 \%$ (Source: Laboratory of Embrapa, Dourados, Mato Grosso do Sul).

Sowing took place on October $21^{\text {st }}, 2008$, where two seeds per cell were placed. The beginning of the emergency occurred on October $24^{\text {th }}, 2008$. On October $30^{\text {th }}, 2008$, nine days after sowing (DAS), it was performed thinning, leaving one plant per container, and the counting of the percentage of seedling emergence. Irrigation was performed manually with the aid of sieve watering until superficial runoff, in the morning and evening, when it was necessary.

Daily, the temperatures of dry bulb and wet bulb were measured at $9 \mathrm{~h} 00,12 \mathrm{~h} 00$ and $15 \mathrm{~h} 00$ within each culture environment, during the period of November $3^{\text {rd }}$ to $20^{\text {th }}, 2009$. Subsequently the relative humidity was determined with the aid of Psychrometric Function Demo software (Table 1).

TABLE 1. Chemical analysis of soil (S). Air temperature of dry bulb (TDB), wet bulb (TWU) and mean relative humidity (RH) at 9 AM, 12 PM, and 3 PM for each environment (A) of cultivation.

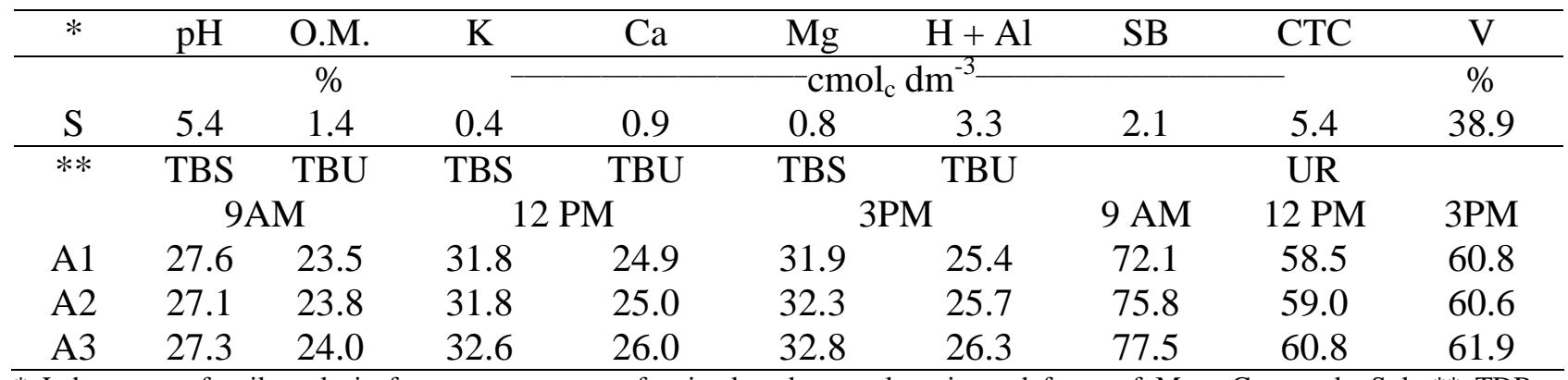

* Laboratory of soil analysis from state agency of animal and vegetal sanitary defense of Mato Grosso do Sul. ** TDB = Temperature of the dry bulb $\left({ }^{\circ} \mathrm{C}\right) ; \mathrm{TWB}=$ temperature of the wet bulb $\left({ }^{\circ} \mathrm{C}\right) ; \mathrm{RH}=$ relative humidity $(\%)$.

At the $30^{\text {th }}$ day, it was measured the plant height $(\mathrm{PH})$, the stem diameter (SD), dry mass of shoot area (DMSA), dry mass of root (DMS) and total dry matter (TDM). It was determined the Dickson quality index (DQI), given by: DQI = TDM / (RAD + RMS). 


\section{RESULTS AND DISCUSSION}

For all variables evaluated in this study, the relation between the mean square of residues (RMSR) of the individual analysis of variance of the experiments did not exceed the ratio of 7:1 (Table 2), therefore allowing the realization of joint analysis of experiments (BANZATTO \& KRONKA, 2006) and the comparison of the protected environment.

TABLE 2. Mean square of residues of the individual analysis (MSR) for plant height (PH), stem diameter (SD), dry mass of the shoot area (DMSA), dry mass of the root (DMR), total dry mass (TDM) and Dickson quality index (DQI) of beetroot seedlings at 30 days after sowing. Aquidauana, state of Mato Grosso do Sul, 2008.

\begin{tabular}{lcccccc}
\hline & \multicolumn{5}{c}{ Mean Square of Residues of the Individual Analysis (MSR) } \\
\hline & PH & SD & MDSA & DMR & TDM & DQI \\
Greenhouse & 0.004713 & 0.003544 & 0.000004 & 11.08 & 0.000005 & 8.07 \\
Sombrite ${ }^{\circledR}$ & 0.003585 & 0.004285 & 0.000001 & 10.60 & 0.000001 & 8.63 \\
Aluminet $^{\circledR}$ & 0.007273 & 0.002779 & 0.000004 & 7.90 & 0.000005 & 5.96 \\
\hline RMSR $^{*}$ & 2.03 & 1.54 & 4.00 & 0.74 & 5.00 & 1.45 \\
\hline * RMSR = relation between the highest and lowest & mean square of residues of the individual analysis in the environment of \\
cultivation.
\end{tabular}

The interactions observed in Tables 3 and 4 in the three factors of beetroot seedling studied (environmental conditions, tray types and substrates), indicate that is interference of cell volume and type of substrate used in the growth and formation of beetroot seedlings, as well as the environmental conditions, interacting and forming seedlings of high quality.

In the interactions between environments of cultivation and containers (Table 3 ) it is verified that in the interface region of Cerrado and Pantanal of Mato Grosso do Sul it is not recommended the use of trays of 200 cells for the production of beetroot seedlings, because the seedlings formed in that container had the lowest parameters in all cultivated environments, with the lowest force expressed by Dickson quality index (Table 3). In the state of São Paulo, TRANI et al. (2004) also do not recommend the use of trays of 200 cells for seedling of vegetables, especially lettuce. By presenting lower volume, compared to trays of 128 and 72 cells, the trays of 200 cells have lower amounts of nutrients, faster water loss and they limit root growth, thus promoting seedlings with lower standards.

It has been found that the higher cell volumes of the trays of 128 and 72 cells, especially the tray of 72, provided the best seedlings (Tables 3 and 4). In these containers, there is greater availability of nutrients and increased opportunities for the growth of the root system, thus producing larger seedlings with more vigor. RODRIGUES et al. (2010), about the formation of tomato seedlings, cultivar Santa Clara 5800, assessing trays with the same cell volumes, found that the trays of 72 cells were more viable, similar to results obtained in this study. But depending on the substrate used, this type of tray did not differ from that of 128 cells. In the Pantanal region, polystyrene trays with 72 cells provide seedlings of beetroot and lettuce of high quality when grown in substrate containing "soil +7 or $14 \%$ commercial organic compost", (LEAL et al., 2011).

In the assessment of environmental conditions for each type of container, it was observed for trays of 128 and 72 cells that shoot area and total dry masses of the seedling did not differ in production environments. However, the root dry mass and the Dickson quality index revealed to the tray of 72 cells that the nursery with Sombrite ${ }^{\circledR}$ was a more favorable environment for seedling development, and for the tray of the 128 cells, the greenhouse was more favorable (Table 3). Similar results were observed by COSTA et al. (2011) for seedlings of eggplant, where they verify that the monofilament screen is the best growing environment when using the tray of 72 cells, and when using the tray of 128 cells, the greenhouse provides better conditions. 
There was little difference in temperature and relative humidity values of the protected environment in times of sampling (Table 1), as observed by COSTA et al. (2010 b) in the formation of passion fruit, who found that the temperatures at the times of $9 \mathrm{~h}, 12 \mathrm{~h}$ and $15 \mathrm{~h}$ of the protected environment (greenhouse, screened and covered with straw) were similar and did not affect the temperature gradient, but there were differences verified in seedling vigor.

This interaction between environment cell volume showed that for the tray of 128 cells, there were less vigorous seedlings in a nursery with Sombrite ${ }^{\circledR}$, where the very structure of the shade mesh, which allowed the entry of rainwater, may have adduced the nutrients from the lower volume of substrate and influenced in seedling development (Table 3). This fact was not verified for the tray of 72 cells, because in this container seedlings showed better development in the nursery. Even being in the same condition of environment of cultivation of the trays of 128 cells, the largest cell volume of the tray of 72 cells allowed carrying less nutrients and better development of the seedlings (COSTA et al., 2011).

TABLE 3. Interactions between environments and containers for plant height $(\mathrm{PH})$, stem diameter (SD), dry mass of the shoot area (DMSA), dry mass of the root (DMR), total dry mass (TDM) and Dickson Quality Index of beetroot seedlings at 30 days after sowing. Aquidauana, state of Mato Grosso do Sul, 2008.

\begin{tabular}{|c|c|c|c|c|c|c|}
\hline & \multicolumn{3}{|c|}{ Plant height $(\mathrm{cm})$} & \multicolumn{3}{|c|}{ Stem diameter $(\mathrm{mm})$} \\
\hline & Greenhouse & Sombrite $^{\circledR}$ & Aluminet $\left.^{(}\right)$ & Greenhouse & Sombrite $^{\circledR}$ & Aluminet $^{(B}$ \\
\hline 72 cells & $2.16 \mathrm{Ab}$ & $2.34 \mathrm{Aa}$ & $2.15 \mathrm{Ab}$ & $1.46 \mathrm{Aa}$ & $1.39 \mathrm{Ab}$ & $1.04 \mathrm{Ac}$ \\
\hline 128 cells & $2.00 \mathrm{Bb}$ & $2.23 \mathrm{Aa}$ & $1.99 \mathrm{Bb}$ & $1.25 \mathrm{Ba}$ & $1.07 \mathrm{Bb}$ & $0.84 \mathrm{Bc}$ \\
\hline \multirow[t]{2}{*}{200 cells } & $1.97 \mathrm{Ba}$ & $1.84 \mathrm{Bb}$ & $1.96 \mathrm{Bab}$ & $0.82 \mathrm{Ca}$ & $0.78 \mathrm{Cab}$ & $0.76 \mathrm{Cb}$ \\
\hline & \multicolumn{3}{|c|}{ Dry mass of the shoot area $(\mathrm{g})$} & \multicolumn{3}{|c|}{ Dry mass of the root $(\mathrm{g})$} \\
\hline 72 cells & $0.0426 \mathrm{Aa}$ & $0.0415 \mathrm{Aa}$ & $0.0374 \mathrm{Aa}$ & $0.0045 \mathrm{Bb}$ & $0.0055 \mathrm{Aa}$ & $0.0043 \mathrm{Ab}$ \\
\hline 128 cells & $0.0319 \mathrm{Ba}$ & $0.0311 \mathrm{Ba}$ & $0.0309 \mathrm{Ba}$ & $0.0057 \mathrm{Aa}$ & $0.0033 \mathrm{Bc}$ & $0.0048 \mathrm{Ab}$ \\
\hline 200 cells & $0.0129 \mathrm{Ca}$ & $0.0107 \mathrm{Ca}$ & $0.0128 \mathrm{Ca}$ & $0.0028 \mathrm{Ca}$ & $0.0018 \mathrm{Cb}$ & $0.0022 \mathrm{Bab}$ \\
\hline & \multicolumn{3}{|c|}{ Total dry mass $(\mathrm{g})$} & & DQI & \\
\hline 72 cells & $0.0471 \mathrm{Aa}$ & $0.0470 \mathrm{Aa}$ & 0.041 & $0.0043 \mathrm{Bb}$ & $0.0052 \mathrm{Aa}$ & $0.0039 \mathrm{Ab}$ \\
\hline 128 cells & $0.0376 \mathrm{Ba}$ & $0.0344 \mathrm{Ba}$ & $0.0357 \mathrm{Ba}$ & $0.0052 \mathrm{Aa}$ & $0.0030 \mathrm{Bc}$ & $0.0038 \mathrm{Ab}$ \\
\hline 200 cells & $0.0156 \mathrm{Ca}$ & $0.0125 \mathrm{Ca}$ & $0.0150 \mathrm{Ca}$ & $0.0022 \mathrm{Ca}$ & $0.0015 \mathrm{Cb}$ & $0.0018 \mathrm{Bab}$ \\
\hline
\end{tabular}

* Same uppercase letters in the columns and lowercase letters in the rows do not differ by Tukey test at $5 \%$ probability.

In interactions between substrates and environments, as well as the interactions between substrates and containers, it was observed that the seedlings grown in vermiculite had higher quality standards, and in coconut fiber had the lowest (Table 4). The physical characteristics of vermiculite, such as porosity and moisture absorption, favored the development of beetroot roots and increased robustness (DQI), producing high quality seedlings. In researches, with the formation of sweet pepper and lettuce seedlings, it was observed with plants with high vigor when grown in vermiculite (OLIVEIRA et al., 2008).

In the coconut fiber, it was observed plants least vigorous (Table 4), as observed by COSTA et al. (2010 c) in the formation of papaya seedlings, and COSTA et al. (2011 b) in the formation of passion fruit seedlings. The coconut fiber presented suitable results for the formation of tomato seedlings in the state of São Paulo (CARRIJO et al., 2002), however, in Aquidauana, state of Mato Grosso do Sul, in this present study, it was found that the seedlings on this substrate showed the lowest DQI (Table 4), as observed by RAMOS et al. (2008) in tomato seedlings. Possibly, a bad composting of the fiber by the manufacturer may have promoted uneven development of the seedlings, because CARRIJO et al. (2002) state that is needed 90 days of composting of this material. However, because it is a material obtained commercially, it is expected that it was ready for seedling use and formation. 
For the seedlings grown in vermiculite, shoot area and total dry mass were higher in seedlings grown in screening; and for the seedlings grown in the soil; masses were higher in the greenhouse (Table 4). Similar results were observed for this substrate by COSTA et al. $(2010 \mathrm{c})$ in the formation of papaya seedlings, and COSTA et al. (2011 b) in the formation of passion fruit seedlings. The physical structure of vermiculite associated with the structure of screened environments, which provided river water input, promoted the accumulation of shoot area dry mass in the seedlings. For seedlings grown in soil substrate associated to a greenhouse, probably the fertilization with $14 \%$ of organic compost to the soil and the mineral fertilizer had produced higher amount of available nutrients and favorable conditions for greater accumulation of biomasses and better humidity retention.

TABLE 4. Interactions between environments and substrates, containers and substrates for plant height (PH), stem diameter (SD), dry mass of the shoot area (DMSA), dry mass of the root (DMR), total dry mass (TDM) and Dickson Quality Index of beetroot seedlings at 30 days after sowing. Aquidauana, state of Mato Grosso do Sul, 2008.

\begin{tabular}{|c|c|c|c|c|c|c|}
\hline & \multicolumn{6}{|c|}{ Plants Height (cm) } \\
\hline & Greenhouse & Sombrite $^{\circledR}$ & Aluminet $^{(B)}$ & 72 cells & 128 cells & 200 cells \\
\hline$\overline{\text { Soil }}$ & $2.02 \mathrm{Ba}$ & $2.05 \mathrm{Ca}$ & $1.68 \mathrm{Bb}$ & $2.22 \mathrm{Ba}$ & $1.99 \mathrm{Cb}$ & $1.54 \mathrm{Dc}$ \\
\hline Plantmax $^{\circledR}$ & $1.98 \mathrm{ABb}$ & $2.42 \mathrm{Aa}$ & $2.44 \mathrm{Aa}$ & $2.33 \mathrm{Ba}$ & $2.45 \mathrm{Aa}$ & $2.06 \mathrm{Bb}$ \\
\hline Fiber & $1.86 \mathrm{Ba}$ & $1.88 \mathrm{Da}$ & $1.53 \mathrm{Bb}$ & $1.79 \mathrm{Ca}$ & $1.64 \mathrm{Db}$ & $1.84 \mathrm{Ca}$ \\
\hline \multirow[t]{2}{*}{ Vermiculite } & $2.31 \mathrm{Ab}$ & $2.20 \mathrm{Bb}$ & $2.49 \mathrm{Aa}$ & $2.53 \mathrm{Aa}$ & $2.21 \mathrm{Bb}$ & $2.26 \mathrm{Ab}$ \\
\hline & \multicolumn{6}{|c|}{ Stem Diameter $(\mathrm{mm})$} \\
\hline Soil & $1.41 \mathrm{Ba}$ & $1.29 \mathrm{Ab}$ & $0.83 \mathrm{Cc}$ & $1.51 \mathrm{Ba}$ & $1.22 \mathrm{Ab}$ & $0.80 \mathrm{Bc}$ \\
\hline Plantmax $^{(\circledR)}$ & $1.09 \mathrm{Ca}$ & $1.08 \mathrm{Ba}$ & $0.92 \mathrm{Bb}$ & $1.14 \mathrm{Ca}$ & $1.08 \mathrm{Bb}$ & $0.87 \mathrm{Ac}$ \\
\hline Fiber & $0.75 \mathrm{Da}$ & $0.67 \mathrm{Cb}$ & $0.54 \mathrm{Dc}$ & $0.71 \mathrm{Da}$ & $0.66 \mathrm{Ca}$ & $0.58 \mathrm{Cb}$ \\
\hline \multirow[t]{2}{*}{ Vermiculite } & $1.47 \mathrm{Aa}$ & $1.28 \mathrm{Ab}$ & $1.22 \mathrm{Ac}$ & $1.83 \mathrm{Aa}$ & $1.25 \mathrm{Ab}$ & $0.89 \mathrm{Ac}$ \\
\hline & \multicolumn{6}{|c|}{ Dry Mass of the Shoot Area (g) } \\
\hline Soil & Aa & $0.0306 \mathrm{Bb}$ & $0.0202 \mathrm{Bc}$ & $0.0426 \mathrm{Ba}$ & $0.0359 \mathrm{Bb}$ & $0.0133 \mathrm{Ac}$ \\
\hline Plantmax ${ }^{\circledR}$ & $.0264 \mathrm{Ba}$ & $0.0234 \mathrm{Ca}$ & $0.0207 \mathrm{Ba}$ & $0.0283 \mathrm{Ca}$ & $0 \mathrm{Ca}$ & $0.0131 \mathrm{Ab}$ \\
\hline Fiber & $0077 \mathrm{Ca}$ & $0.0067 \mathrm{Da}$ & $0.0063 \mathrm{Ca}$ & $0.0072 \mathrm{Da}$ & $0.0075 \mathrm{Da}$ & $0.0061 \mathrm{Ba}$ \\
\hline \multirow[t]{2}{*}{ Vermiculite } & $0415 \mathrm{Ac}$ & $0.0505 \mathrm{Ab}$ & $0.0611 \mathrm{Aa}$ & $0.0840 \mathrm{Aa}$ & $0 \mathrm{Ab}$ & $0.0161 \mathrm{Ac}$ \\
\hline & \multicolumn{6}{|c|}{ Dry Mass of the Root (g) } \\
\hline Soil & $\mathrm{Ba}$ & $0.0039 \mathrm{Bab}$ & $0.0032 \mathrm{Bb}$ & $0.0047 \mathrm{Ba}$ & $0.0046 \mathrm{Ba}$ & $0.0025 \mathrm{Ab}$ \\
\hline Plantm & $0.0049 \mathrm{Ba}$ & $0.0031 \mathrm{Bb}$ & $0.0028 \mathrm{Bb}$ & $0.0037 \mathrm{Cb}$ & $0.0046 \mathrm{Ba}$ & $0.0025 \mathrm{Ac}$ \\
\hline Fiber & $\mathrm{Cb}$ & 0.00 & $0.0025 \mathrm{Ba}$ & $0.0014 \mathrm{Db}$ & $0.0025 \mathrm{Ca}$ & $0.0012 \mathrm{Bb}$ \\
\hline \multirow[t]{2}{*}{ Vermiculite } & $0063 \mathrm{Aa}$ & $0.0060 \mathrm{Aa}$ & $0.0064 \mathrm{Aa}$ & $0.0094 \mathrm{Aa}$ & $0.0065 \mathrm{Ab}$ & $0.0028 \mathrm{Ac}$ \\
\hline & \multicolumn{6}{|c|}{ Total Dry Mass (g) } \\
\hline Soil & $\mathrm{Aa}$ & 0.03 & $0.0234 \mathrm{Bc}$ & $0.0473 \mathrm{Ba}$ & $\mathrm{Ba}$ & $0.0157 \mathrm{Ab}$ \\
\hline Plantmax ${ }^{\circledR}$ & $0.0313 \mathrm{Ba}$ & $0.0265 \mathrm{Cab}$ & $0.0234 \mathrm{Bb}$ & $0.0319 \mathrm{Ca}$ & $36 \mathrm{Ba}$ & $0.0156 \mathrm{Ab}$ \\
\hline Fiber & $0.0091 \mathrm{Ca}$ & $0.0079 \mathrm{Da}$ & $0.0088 \mathrm{Ca}$ & $0.0086 \mathrm{Da}$ & $0.0100 \mathrm{Ca}$ & $0.0073 \mathrm{Ba}$ \\
\hline \multirow[t]{2}{*}{ Vermiculite } & $0.0478 \mathrm{Ac}$ & $0.0564 \mathrm{Ab}$ & $0.0675 \mathrm{Aa}$ & $0.0934 \mathrm{Aa}$ & $0.0595 \mathrm{Ab}$ & $0.0189 \mathrm{Ac}$ \\
\hline & \multicolumn{6}{|c|}{ Dickson Quality Index } \\
\hline Soil & $0.0045 \mathrm{Ba}$ & $0.0036 \mathrm{Bb}$ & $0.0028 \mathrm{Bc}$ & $0.0044 \mathrm{Ba}$ & $0.0043 \mathrm{Ba}$ & $0.0021 \mathrm{Ab}$ \\
\hline Plantm & $0.0044 \mathrm{Ba}$ & $0.0027 \mathrm{Cb}$ & $0.0023 \mathrm{Bb}$ & $0.0033 \mathrm{Cb}$ & $0.0040 \mathrm{Ba}$ & $0.0021 \mathrm{Ac}$ \\
\hline Fiber & $0.0011 \mathrm{Cab}$ & $0.0009 \mathrm{Db}$ & $0.0016 \mathrm{Ca}$ & $0.0011 \mathrm{Dab}$ & $0.0016 \mathrm{Ca}$ & $0.0008 \mathrm{Bb}$ \\
\hline Vermiculite & $0.0057 \mathrm{Aa}$ & $0.0056 \mathrm{Aa}$ & $0.0059 \mathrm{Aa}$ & $0.0090 \mathrm{Aa}$ & $0.0059 \mathrm{Ab}$ & $0.0023 \mathrm{Ac}$ \\
\hline
\end{tabular}

* Same letters uppercase in the columns and lowercase letters in the rows do not differ by Tukey test at 5\% probability.

\section{CONCLUSIONS}

The monofilament screen was the best environment for seedlings of beetroot produced in the tray of 72 cells, and those produced in trays of 128 cells, the greenhouse was the best. 
The best beetroot seedlings were formed in the tray of 72 cells.

The vermiculite was the best substrate for beetroot seedling.

\section{ACKNOWLEDGEMENT}

The authors thank the Dean of Research and Graduate Studies (PROPP) of the State University of Mato Grosso do Sul (UEMS), for the resources for the research.

\section{REFERENCES}

BANZATTO, D.A.; KRONKA, S.N. Experimentação agrícola. 4.ed. Jaboticabal: FUNEP/UNESP, 2006. 237 p.

BOLETIM ANUAL 2011. Comercialização anual da CEASA/MS em 2010. Campo Grande: Governo do Estado, 2011. Disponível em: <www.ceasa.ms.gov.br>. Acesso em: 15 maio 2011.

CARRIJO, O.A.; LIZ, R.S.; MAKISHIMA, N. Fibra da casca do coco verde como substrato agrícola. Horticultura Brasileira, Brasília, v.20, n.4, p.533-535, 2002.

COSTA, E.; VIEIRA, L.C.R.; RODRIGUES, E.T.; MACHADO, D.; BRAGA, A.B.P.; GOMES, V.A. Ambientes, recipientes e substratos na formação de mudas de pepino híbrido. Agrarian, Dourados, v.2, n.4, p.95-116, 2009.

COSTA, E.; LEAL, P.A.M.; GOMES, V.A.; MACHADO, D.; JARA, M.C.S. Biomassa de mudas de pepinos híbridos conduzidos sob ambientes protegidos. Bragantia, Campinas, v.69, n.2, p.381386, 2010 a.

COSTA, E.; LEAL, P.A.M.; SASSAQUI, A.R.; GOMES,V.A. Doses de composto orgânico comercial na composição de substratos para a produção de mudas de maracujazeiro em diferentes tipos de cultivo protegido. Engenharia Agrícola, Jaboticabal, v.30, n.5, p.776-787, 2010b.

COSTA, E ; GOMES, V.A.; LEAL, P.A.M.; ABOT, A.R.; FERNANDES, C.D. Formação de mudas de mamão em ambientes de cultivo protegido em diferentes substratos. Revista Ceres, Viçosa, v.57, n.5, p.679-685, 2010c.

COSTA, E.; DURANTE, L.G.Y.; NAGEL, P.L.; FERREIRA, C.R.; SANTOS, A. Qualidade de mudas de berinjela submetida a diferentes métodos de produção. Revista Ciência Agronômica, Fortaleza, v.42, n.4, p.1017-1025, 2011a.

COSTA, E.; SANTOS, L.C.R.; CARVALHO, C.; LEAL, P.A.M.; GOMES, V.A. Volumes de substratos comerciais, solo e composto orgânico afetando a formação de mudas de maracujazeiroamarelo em diferentes ambientes de cultivo. Revista Ceres, Viçosa, v.58, n.2, p.216-222, 2011 b.

FERREIRA, D.F. SISVAR - Sistema de análise de variância. Versão 5.3. Lavras: UFLA, 2010.

GRANGEIRO, L.C.; NEGREIROS, M.Z.; SOUZA, B.S.; AZEVEDO, P.E.; OLIVEIRA, S.K.L.; MEDEIROS, M.A. Acúmulo e exportação de nutrientes em beterraba. Ciência e Agrotecnologia, Lavras, v.31, n.2, p.267-273, 2007.

GUIMARÃES, V.F.; ECHER, M.M.; MINAMI, K. Métodos de produção de mudas, distribuição de matéria seca e produtividade de plantas de beterraba. Horticultura Brasileira, Brasília, v.20, n.3, p.505-509, 2002.

LEAL, P.A.M.; COSTA, E.; SCHIAVO. J.A.; PEGORARE, A.B. Formação de mudas e produção a campo de beterraba e alface em Aquidauana-MS. Horticultura Brasileira, Brasília, v.29, n.4, p.457463, 2011.

MARQUES, P.A.A.; BALDOTTO, P.V.; SANTOS, A.C.P.; OLIVEIRA, L. Qualidade de mudas de alface formadas em bandejas de isopor com diferentes números de células. Horticultura Brasileira, Brasília, v.21, n.4, p.649-651, 2003. 
OLIVEIRA, D.A.; FERNANDES, B.M.; RODRIGUES, J.J.V.; OLIVEIRA, R.A.; COSTA, F. G.B. Produção de mudas de pimentão e alface em diferentes combinações de substrato. Revista Verde de Agroecologia e Desenvolvimento Sustentável, Mossoró, v.3, n.1, p.133-137, 2008.

RAMOS, S.J.; GUILHERME, D.O.; CALDEIRA JUNIOR, C.F.; SAMPAIO, R.A.; COSTA, C.A.; FERNANDES, L.A. Tomato seedling production in substrate containing coconut fiber and mushroom culture waste. Agrária, Recife, v.3, n.3, p.237-241, 2008.

RODRIGUES, E.T.; LEAL, P.A.M.; COSTA, E.; PAULA, T.S.; GOMES, V. A. Produção de mudas de tomateiro em diferentes substratos e recipientes em ambiente protegido. Horticultura Brasileira, Brasília, v.28, n.4, p.483-488, 2010.

TAKUSHI, S.A.M.; TANAKA, A.C.D.; GALLO, P.R.; BRESOLIN, A.M.B. Perspectiva de alimentação infantil obtida com gestantes atendidas em centros de saúde na cidade de São Paulo. Revista Brasileira de Saúde Materno Infantil, Recife, v.6, n.1, p.115-125, 2006.

TRANI, P.E.; NOVO, M.C.S.S.; CAVALLARO JÚNIOR, M.L.; TELLES, L.M.G. Produção de mudas de alface em bandejas e substratos comerciais. Horticultura Brasileira, Brasília, v.22, n.2, p.290-294, 2004. 